\title{
SCHUR-CONVEXITY OF THE WEIGHTED ČEBYŠEV FUNCTIONAL II
}

\section{V. ČULJAK}

Abstract. In this paper the weighted Čebyšev functional $T(p ; f, g ; a, b)$ is regarded as a function of two variables

$$
T(p ; f, g ; x, y)=\frac{\int_{x}^{y} p(t) f(t) g(t) d t}{\int_{x}^{y} p(t) d t}-\left(\frac{\int_{x}^{y} p(t) f(t) d t}{\int_{x}^{y} p(t) d t}\right)\left(\frac{\int_{x}^{y} p(t) g(t) d t}{\int_{x}^{y} p(t) d t}\right),(x, y) \in[a, b] \times[a, b]
$$

where $f, g$ and $p>0$ are Lebesgue integrable functions. For a function

$$
K(p ; f, g ; x, y)=\left(\int_{x}^{y} p(t) d t\right)^{2} T(p ; f, g ; x, y)(x, y) \in[a, b] \times[a, b]
$$

the property of Schur-covexity, Schur-geometric convexity, Schur-harmonic convexity and $(1,1)$ convexity is proved.

Mathematics subject classification (2010): Primary 26D15, Secondary 26D99.

Keywords and phrases: Convex functions, Schur-convex function, Čebyšev functional.

\section{REFERENCES}

[1] G. D. Anderson, M. K. Vamanamurthy, M. Vuorinen, Generalized convexity and inequalities, Journal of Mathematical Analysis and Applications 335, 2 (2007), 1294-1308.

[2] Y. Chu AND Y.-P. LV, The Schur harmonic convexity of the Hamy symmetric function and its applications, Journal of Inequalities and Applications, Vol. 2009 (2009), Article ID 838529, 10 pages.

[3] Y. Chu, X. Zhang And G. WANG, The Schur Geometrical Convexity of the Extended Mean Values, Journal of Convex Analysis 15 (2008), 707-718.

[4] V. ČUlJAK AND J. PeČARIĆ, Schur-convexity of Čebišev functional, Mathematical Inequalities \& Applications, accepted for publication.

[5] V. ČULJAK, Schur-convexity of the weighted Čebišev functional, Journal of Mathematical Inequalities 5, 2 (2011), 213-217.

[6] H.-N. Shi AND J. Zhang, Schur-convexity and Schur-geometric convexity of Čebišev functional, RGMIA 30, 3 (2000), 853-856.

[7] G. H. Hardy, J. E. Littlewood and G.Polya, Inequalities, Cambrige, 1934, 1952.

[8] A. W. Marshall And I. Olkin, Inequalities: Theory of Majorization and Its Applications, Academic Press Inc., New York, 1979.

[9] D. S. Mitrinović, J. E. PeČArić And A. M. Fink, Classical and New Inequalities in Analysis, Kluwer Academic Publishers, 1993.

[10] C. P. Niculescu And L.-E. Persson, Convex Functions and Their Applications. A Contemporary Approach, CMS Books in Mathematics/Ouvrages de Mathématiques de la SMC, 23, Springer, New York, NY, USA, 2006.

[11] J. E. PeČArić, F. Proschan, AND Y. L. Tong, Convex functions, partial orderings, and statistical applications, Academic Press Inc., 1992.

[12] T. Popoviciu, Les functions convexes, Herman and Cie Editeurs, Paris, 1944.

[13] H.-N. SHI, Y.-M. JIANG AND W.-D. JIANG, Schur-convexity and Schur-geometrically concavity of Gini means, Computers \& Mathematics with Applications 57, 2 (2009), 266-274.

[14] W. Xia And Y. Chu, The Schur Harmonic Convexity of Lehmer Means, International Mathematical Forum 4, 41 (2009), 2009-2015. 
[15] X. M. Zhang, Geometrically Convex Functions, Hefei: An'hui University Press, 2004. (Chinese)

[16] X. M. Zhang, S-Geometric Convexity of a function involving MacLaurin's elementay symmetric mean, Journal of inequalities in pure and applied mathematics 8, 2 (2007), art. 51.

[17] L.-C. WANG, On the Monotonicity of Difference Generated by the Inequalities of Čebyšev Type, Journal of Sichuan University, Natural Science Edition 39, 3 (2002), 398-403. (Chinese) 